\title{
Reading the Qur'an Contextually
}

On June 6, 2013, at the IIIT headquarters in Herndon, VA, Abdulla Saeed (Sultan of Oman Professor of Arab and Islamic Studies, University of Melbourne, Australia), spoke to the audience about how a "contextualist" reading of the Qur'an is becoming popular among those Muslims who are often referred to as "progressives," "ijtihadis," or "contextualists." 
Saeed began his presentation by defining context, which he said goes hand in hand with text, in two ways: (1) the linguistic context of the text in which the verse actually functions and (2) the macro-context of the text, which encompasses the social, politicial, economic, intellectual, and cultural milieux in which a particular text functions. But despite the importance of this latter approach, many Qur'anic scholars do not use it because they have traditionally been far more interested in a word for word analysis, examining particular phrases, and maybe providing some explanations in light of hadith or juristic understandings. Thus it has never really been part of the tafsir tradition. The science of asbāb al-nuzūl (the occasions of the revelation) is of some help, but only gives a rather limited and insufficient understanding of the context.

He then moved to what he terms the textualist and contextualist approaches. People who follow the first one are very focused on the text's linguistic meaning and see it as the basis - and maybe the only way - to understanding the text. Those who follow the second one are more interested in keeping an eye on the linguistic meaning as well as the macro-context in which the text functions. A grey area, which can be thought of as a continuum, exists between them.

Three types of text were posited: theological (e.g., the World of the Unseen), historically oriented (e.g., past prophets, communitites, and events), and ethico-legal texts (e.g., instructions, advice, rules and regulations, gender, marriage, and divorce). He is concerned with this third type, which poses particular challenges as regards how such texts are to be made relevant to the changed circumstances of the contemporary world. In fact, this is the topic of his forthcoming book: Reading the Qur'an in the Twenty-First Century: Towards a Contextualist Approach.

A contextualist approach can be defined as a way of reading the Qu'anic text and its meaning as they were understood by the Companions and relating the ensuing understanding to the newly emerging contexts and situations that have arisen due to time and place. Some Muslims assert that since these rulings are in the Qur'an they must be relevant. Others agree, but go further by asking how are they relevant today?

Why, he asked, do some contemporary Muslims feel the need for a new approach? Is something wrong with the traditional ones? Even if there is nothing wrong with them, certain interpretations have become somewhat problematic for the contemporary era. There is a certain way of approaching ethico-legal texts, that of fiqh, which is "textualist" and therefore literal. Such a linguisticfocused analysis stresses the tranditional approach, for since God knows everything there is no need to reinterpret anything. But following this approach can lead to problems with, for example, such Qur'anic texts as 4:34- 
Men shall take full care of women with the bounties which God has bestowed more abundantly on the former than on the latter, and with what they may spend out of their possessions. And the righteous women are the truly devout ones, who guard the intimacy which God has [ordained to be] guarded. And as for those women whose ill-will you have reason to fear, admonish them [first]; then leave them alone in bed; then beat them; and if thereupon they pay you heed, do not seek to harm them. Behold, God is indeed most high, great!

- and gender equality. He discussed the first part only via the different translations: "in charge of women" (Pickthall), "the protectors and maintainers of women" (Yusuf Ali), and " should take good care of women" (Abdul Halim). All of these very different readings depend on where one is coming from and what ideas one has. The classical tafāsìr have roughly the same basic framework: women must be subject to men's authority, an assertion that they support via the Hadith literature. They saw no need to contextualize this verse, because their societies did not warrant it.

But when the role of women began to change significantly during the twentieth century (e.g., education, wealth, and economic power), people began asking if there was a problem with the Qur'anic text or with the commentators' interpretation of it. For example, a contextualist approach could go a long way toward meeting women's changed role without engaging in any textual manipulation. He finds the current belief held by some Muslims that one can go from the twenty-first century to the seventh century without the mediation of the tradition to be very problematic, for he holds that the tradition can help Muslims better understand the text.

Saeed then mentioned several key features that interpreters must consider: (1) there is no such thing as a totally objective interpretation, for it contains each person's presuppositions, values, beliefs, likes, and dislikes; (2) the understanding of a text is not fixed forever, for there are shifts in meanings, changes, and different emphases by scholars; (3) language is often ambiguous; and (4) how the Qur'anic text was understood in the early part of the seventh century. For example, what did the original audience focus on, deemphasize, and marginalize? How was it understood by subsequent generations who did exactly the same thing? How is it understood in today's contexts, which reflect the diversity of the very diverse Muslim world? There are always other possible readings that have to be at least considered.

Also, certain values are mentioned so many times in the Qur'an (e.g., mercy, justice, fairness, and equity) that they form its worldview, the basic understanding of law and ethics, and the text's "higher objectives." Just be- 
cause they are very abstract is no reason to ignore them. In addition, parallel texts must be analyzed. For example, Q. 4:34 is not the only verse dealing with male-female relationships. However, one needs to be cautious when using other texts to interpret the Qur'an, expecially the Hadith literature. For example, Q. 4:34's understanding has been influenced by this literature's negative view of women.

In connection with this, the whole issue of the hadiths' authenticity needs to be looked at, for its status was determined by the report's chain of transmission and not its text, even if the latter had clear problems. As a result, various scholars throughout history have challenged even the "authentic" hadiths found in al-Bukhari and Muslim. Muslims need to develop some criterion to determine whether hadiths can be considered reliable or not, are in line with the Prophet's known behavior and actions, and if they violate common sense and reason. Many prominent hadith scholars even in the classical era raised this issue.

The textualists argue that the contextualist approach undermines the stability of the Qur'anic meaning and the Shari'ah, reads into the Qur'anic text whatever appears in the modern period (e.g., human rights and gender equality), has no basis in Islamic thought and thus is a modern invention that must be rejected, and that their method provides the most authentic and appropriate understanding of the Qur'anic text.

In conclusion, Saeed stated that the contextualist approach is a principled one for it is based on principles. He also asserted that this approach is nothing new, for even Umar employed it during his reign, as can be seen when his actions differed from those of the Prophet (e.g., not giving zakat to categories of people mentioned in the Qur'an). Jurists have also used the concept of the "ambiguity of the language" to develop a whole range of laws to suit people's circumstances, needs, and contexts.

A lively question and answer session followed.

Jay Willoughby

AJISS

Herndon, VA 